\title{
EFFECT OF DIFFERENT METHODS OF APPLICATION OF Zn WITH REDUCED NPK FERTILIZER LEVELS ON GROWTH, YIELD AND GRAIN QUALITY OF TRANSPLANT RICE (Oryza sativa. L) VAR. AT 362
}

\author{
Kumara $\mathrm{KHCH}^{1 *}$, Hafeel $\mathrm{RF}^{1}$, Mirihagalla $\mathrm{MKPN}^{2}$ and Wathugala $\mathrm{DL}^{2}$ \\ ${ }^{1}$ Rice Research Station, Department of Agriculture, Ambalantota, Sri Lanka \\ ${ }^{2}$ Department of Crop Science, Faculty of Agriculture, University of Ruhuna, Kamburupitiya, \\ Sri Lanka
}

Received: 2021.02.11, Accepted: 2021.05.18

\begin{abstract}
An experiment was conducted during the 2018/2019 Maha and 2019 Yala seasons at Rice Research Station, Ambalantota, Sri Lanka to investigate the effect of different methods of $\mathrm{Zn}$ application on growth, yield and grain quality in different reduced levels of NPK application on rice var. At 362. The trials consisted of 10 treatments which included three levels of NPK $(100,80$ and $65 \%$ levels from the recommended dose) and three methods of the application of $\mathrm{Zn}$ fertilizer viz. broadcasting of $8 \mathrm{~kg} / \mathrm{ha} \mathrm{ZnSO}_{4}$ two weeks after transplanting, dipping seedling roots in $1.5 \% \mathrm{ZnSO}_{4}$ solution for 20 minutes and foliar spraying of $0.5 \%, \mathrm{ZnSO}_{4}, 2,4$ and 6 weeks after transplanting. A randomized complete block design was used with four replicates for the experiment. All tested growth, yield and grain quality parameters showed statistically insignificant results indicating that there is no effect of rate and method of $\mathrm{Zn}$ application but there is a possibility to reduce the level of NPK application up to $65 \%$ with the application of $\mathrm{ZnSO}_{4}$. When considering the labour requirement, materials used and the time spent for treatments, the root dipping at the time of transplanting can be identified as the easiest and cost-effective method for the application of $\mathrm{Zn}$ for rice.
\end{abstract}

Keywords: Foliar spray, Rice, Root dipping, Soil application, $\mathrm{ZnSO}_{4}$

\section{INTRODUCTION}

Oryza sativa (rice) is an edible starchy cereal grain that belongs to the family Poaceae. Roughly rice is the most widely consumed staple food over $50 \%$ of the human population in the world mainly the Asian and African continents (FAO 2008; Rehmani et al. 2014). It has been reported that rice can fulfil $21 \%$ and $15 \%$ of global energy and protein requirements, respectively (Depar et al. 2011). Global consumption of rice slightly increased over the last several years (Abdullah et al. 2006). In Sri Lanka, $40 \%$ of arable land is under paddy cultivation. Rice is a salient food in Sri Lanka's diet (USDA 2020).

Traditionally, rice cultivation is done by flooding the fields while, or after, setting the young seedlings. Continuous harvesting, depletion of

\footnotetext{
*Corresponding author: harsha.hewage@yahoo.com
}

soil nutrients, less adequate irrigation water, climatic effects, unbalanced supply of macro and micronutrients are the reasons for decreasing the productivity of traditional paddy lands (USDA 2020). The most common zinc $(\mathrm{Zn})$ deficiency have been identified as responsible for yield reduction in rice (Fageria et al. 2002; Quijano-Guerta et al. 2002). As mentioned by Alloway (2009) not only in rice, $\mathrm{Zn}$ deficiency is a common micronutrient deficiency in all cereal production worldwide. Alloway (2009) further mentioned that 50\% of cereal cultivation in the world is done in $\mathrm{Zn}$ deficient lands and the deficiency of $\mathrm{Zn}$ reduces the yield as well as the nutrient content of cereals.

Zn deficiency in humans affects physical growth, the functioning of the immune sys- 
tem, reproductive health, and neurobehavioral development (Alloway 2008). Therefore, the biofortification of $\mathrm{Zn}$ is receiving increasing attention to reduce the human $\mathrm{Zn}$ deficiencies. Among various biofortification methods, increasing $\mathrm{Zn}$ fertilization is the easiest and most cost-effective method (Cakmak 2008). Zinc is generally absorbed by plants in its ionic form $\mathrm{Zn}^{2+}$ by the root system (Rahman et al. 2007).

Various soil types such as alkaline, saline, and water-logged soils with high calcium carbonate, phosphate, magnesium and/or bicarbonate concentrations lead to $\mathrm{Zn}$ deficiency (Alloway 2008; Fageria 2002). Frequent flooding and submergence in rice fields change the $\mathrm{pH}$ and it affects the $\mathrm{Zn}$ deficiency by declining available $\mathrm{Zn}$ and the formation of insoluble $\mathrm{Zn}$ compounds (Jhonson-Beebout 2009). In 2008, Alloway has reported that the Zinc solubility decreases 100 -fold for each unit increase in $\mathrm{pH}$. All these facts indicate that $\mathrm{Zn}$ deficiency can easily occur and common in traditional rice cultivating lands. Many research findings have proven that $\mathrm{Zn}$ deficiency is a common problem in worldwide rice growing areas including Sri Lanka (Alloway 2008; Fitzgerald et al. 2009; Tiong et al. 2014).

Zinc is an essential constituent of the various physiological process of the plant. For instance, activation of enzymes, metabolism of carbohydrates, lipids, auxins, and nucleic acids, protein synthesis can be indicated as some of those (Cakmak 2000a and b; Chang et al. 2005). The plants with $\mathrm{Zn}$ deficiency have reduced leaf chlorophyll content and lower chlorophyll a:b ratio. Therefore, Zn deficiency directly affects the quantum efficiency of the photosystem-II units and also $\mathrm{Zn}$ is a constituent of carbonic anhydrase enzyme which is important for photosynthesis. Therefore, the deficiency of $\mathrm{Zn}$ directly affects yield reduction (Chen et al., 2008). Rice yield can often be reduced by about $20 \%$ without showing $\mathrm{Zn}$ deficiency symptoms (Alloway 2008).

Experiments have been conducted to determine suitable $\mathrm{Zn}$ application methods for rice by many researchers (Khan et al. 2003; Rahman et al. 2007; Rana and Kashif 2014; Ghoneim 2016) and have found that flood-irrigated rice is highly sensitive to $\mathrm{Zn}$ deficiency and availability (Chhabra and Kumar 2018). A study shows that Zn-EDTA application (incorporated in the soil 14 days after transplanting) along with recommended NPK proved to be appropriate to ameliorate $\mathrm{Zn}$ deficiency under climatic conditions of Pakistan. This study has also proven that soil application of Zn-EDTA can significantly increase yield components and nutrient contents in paddy grains and straw. They have also found, basal application of $\mathrm{Zn}$ is an effective method to obtain higher grain yield. The increased yield and yield components were observed by Khan et al. (2003) with different methods of $\mathrm{Zn}$ fertilization. The methods they tried were nursery root dipping in $1 \% \mathrm{ZnSO}_{4}, 0.2 \%$ $\mathrm{ZnSO}_{4}$ solution spray after transplanting and $10 \mathrm{~kg} \mathrm{Zn} / \mathrm{ha}$ by field broadcast method. Rehman et al. (2012) observed that application of $\mathrm{N}$ along with $\mathrm{Zn}$ increased paddy yield and paddy-to-straw ratio significantly in calcareous soils. They have concluded the results saying that the application of nitrogen alone was not so helpful in improving growth and paddy yield but the application of $\mathrm{N}$ along with $\mathrm{Zn}$ had a synergistic effect on $\mathrm{N}$ and $\mathrm{Zn}$ uptake in rice.

Once identified, $\mathrm{Zn}$ deficient soils can be easily treated with $\mathrm{Zn}$ fertilizers to provide an adequate supply of $\mathrm{Zn}$ to rice crops. Several $\mathrm{Zn}$ compounds are utilized as fertilizers for rice but $\mathrm{ZnSO}_{4}$ is the most frequently broadcasted one in paddy cultivations (Alloway 2008). Growing Zn-efficient varieties that can tolerate high bicarbonate and low plant-available zinc concentrations, broadcast $\mathrm{ZnSO}_{4}$ to the nursery beds, dipping seedlings, or presoaking seeds, in a $2-4 \%$ zinc oxide suspension are some $\mathrm{Zn}$ deficiency ameliorating methods reported by researchers (Ghoneim 2016; Khan et al. 2003; Alloway 2008). Chandrajith et al. (2005) and Bandara et al. (2006) highlighted deficiencies in trace elements including $\mathrm{Zn}$ in paddy soils in Sri Lanka. Therefore, considering all these facts and the guidance of the world health organization, the Department of Agriculture (DOA) Sri Lanka has been recommended the application of $\mathrm{ZnSO}_{4}$ for paddy fields at the rate of $5 \mathrm{~kg} / \mathrm{ha}$. Various other fertilizers with micro- 
nutrients are also now popular among paddy farmers although the prices are considerably higher. Therefore, this study was done to determine the effect of different methods of application of $\mathrm{Zn}$ in varying concentrations along with the different fertilizer levels on growth, yield, and grain quality of rice variety AT 362 under Sri Lankan conditions.

\section{MATERIALS AND METHODS}

A field investigation was carried out at Ambalantota Rice Research Station, Sri Lanka during the 2018/2019 Maha and 2019 Yala seasons. The study area belongs to the Low Country Dry Zone agro-ecological region (DL1) and is geographically located in the southern part of Sri Lanka. The experiment was laid out in randomized complete block design, with 4 blocks and 1 replicate in each block. The experiment was carried out with 10 packages with different amount of $\mathrm{N}: \mathrm{P}: \mathrm{K}$ and different method of the application of $\mathrm{ZnSO}_{4}$ as treatments. Fourteen-day-old seedlings of the rice variety AT 362 (three and half months variety) sown on trays were used for field planting. Transplanting in the field was done on the $2^{\text {nd }}$ November 2018 and $29^{\text {th }}$ May 2019 in the Maha and Yala seasons, respectively. The area of a plot was $6 \times 3 \mathrm{~m}(18$ $\mathrm{m} 2$ ) and each plot was separated from a 20-25 inch bund. Three $\mathrm{N}+\mathrm{P}_{2} \mathrm{O}_{5}+\mathrm{K}_{2} \mathrm{O}$ levels (NPK) namely $100 \%$ (225:55:60 kg/ ha), $80 \%$ $(180: 44: 48 \mathrm{~kg} / \mathrm{ha})$ and $65 \%(146: 36: 39 \mathrm{~kg} / \mathrm{ha})$ from the fertilizer recommendation for rice by the Department of Agriculture, Sri Lanka were used along with three methods of application of $\mathrm{Zn}$ fertilizer (soil application-SA, root dipping-RD and foliar spray-FS). The amount of urea was added in 4 splits in 2, 4, 6 and 7 weeks after transplanting, whereas muriate of potash was added in 2 splits in 4 and 6 weeks after transplanting. As basal fertilizer triple supper phosphate was added. In direct soil application of $\mathrm{Zn}$ fertilizer, $8 \mathrm{~kg} / \mathrm{ha}$ $\mathrm{ZnSO}_{4}$ was applied 2 weeks after transplanting. For root dipping and foliar application $1.5 \%$ and $0.5 \%, \mathrm{ZnSO}_{4}$ solutions were used, respectively. The treatments were decided by referring to the experiment done by Begum et al. (2003) and the guidance given by the soil scientists attached to the Department of Agriculture, Sri Lanka with their experiences.
Root dipping was done at the time of transplanting for 20 minutes, while in the foliar application method $2.5 \mathrm{~L}$ of the solution was sprayed to each plot 2, 4 and 6 weeks after transplanting.

Therefore 10 packages viz. T1:100\% NPK, $\mathrm{T} 2: 100 \% \quad \mathrm{NPK}+\mathrm{Zn}+\mathrm{SA}, \quad \mathrm{T} 3: 100 \%$ $\mathrm{NPK}+\mathrm{Zn}+\mathrm{RD}, \quad \mathrm{T} 4: 100 \% \quad \mathrm{NPK}+\mathrm{Zn}+\mathrm{FS}$, T5:80\% NPK $+Z n+S A, \quad$ T6:80\% $\mathrm{NPK}+\mathrm{Zn}+\mathrm{RD}, \mathrm{T} 7: 80 \% \mathrm{NPK}+\mathrm{Zn}+\mathrm{FS}, \mathrm{T} 8: 65 \%$ $\mathrm{NPK}+\mathrm{Zn}+\mathrm{SA}, \quad \mathrm{T} 9: 65 \% \quad \mathrm{NPK}+\mathrm{Zn}+\mathrm{RD}$ and, T10:65\% NPK+Zn+FS were used for the study. All the other cultural practices were same for all the treatments.

Ten weeks after transplanting plant height, leaf area per plant and number of tillers per plant were recorded by uprooting 5 randomly selected plants leaving the border effect from each plot. At harvesting the number of panicles per plant, the number of filled grains per panicle, straw weight and yield were recorded. As gain quality parameters, brown rice, total milled rice and head grain percentages were taken along with 1000 grain weight, grain length and width, with and without husk. Data were analysed using SAS portable version 9.1.3 and means were separated using DMRT.

\section{RESULTS AND DISCUSSION}

The growth and yield parameters namely plant height, leaf area and yield/ha did not show significant differences among the treatments in both Yala and Maha seasons (Table1). The number of panicles $/ \mathrm{m}^{2}$ in Yala season and the number of filled grains per panicle in Maha season also did not show a significant difference among treatments (Table 1). The other growth parameters, viz. the number of tillers/ $\mathrm{m}^{2}$ and straw weight have shown significant differences among treatments in both seasons. However, when comparing both seasons there was no uniformity in these differences. Similarly, selected parameters taken to evaluate the effects on gain quality did not show a significant difference. However, these results imply the possibility of the reduction of the level of $\mathrm{N}: \mathrm{P}: \mathrm{K}$ application to $65 \%$ with the application of $\mathrm{ZnSO}_{4}$. Because the yield of rice did not show significant differences among $100 \%$ and $65 \%$ N:P:K applications. Considering the sta- 
Table 1: Effect of rate of application of NPK and method of application of $\mathrm{ZnSO}_{4}$ on growth and yield of rice var. At 362

\begin{tabular}{|c|c|c|c|c|c|c|c|}
\hline \multicolumn{8}{|c|}{ Yala season } \\
\hline Treatment & $\begin{array}{l}\text { Plant } \\
\text { height } \\
\text { (cm) }\end{array}$ & $\begin{array}{l}\text { No. of till- } \\
\mathrm{ers} / \mathbf{m}^{2}\end{array}$ & $\begin{array}{l}\text { No. of } \\
\text { panicles/ } \\
\text { m }^{2}\end{array}$ & $\begin{array}{l}\text { Straw } \\
\text { weight } \\
\left(\mathrm{kg} / \mathrm{m}^{2}\right)\end{array}$ & $\begin{array}{l}\text { No. of } \\
\text { filled } \\
\text { grains/ } \\
\text { panicle }\end{array}$ & $\begin{array}{l}\text { Leaf area } \\
\left(\mathrm{cm}^{2}\right)\end{array}$ & $\begin{array}{l}\text { Yield (t/ } \\
\text { ha) }\end{array}$ \\
\hline NPK 100\% & $107.71^{\mathrm{a}}$ & $423.01^{\mathrm{a}}$ & $266.38^{\mathrm{a}}$ & $0.66^{\mathrm{ab}}$ & $148.17^{\mathrm{ab}}$ & $786.47^{\mathrm{a}}$ & $6.40^{\mathrm{a}}$ \\
\hline NPK $100 \%+Z n(S A)$ & $107.10^{\mathrm{a}}$ & $404.89^{\mathrm{ab}}$ & $277.18^{\mathrm{a}}$ & $0.71^{\mathrm{ab}}$ & $119.92^{\mathrm{ab}}$ & $716.88^{a}$ & $6.77^{\mathrm{a}}$ \\
\hline NPK 100\%+Zn (RD) & $106.93^{\mathrm{a}}$ & $376.81^{\mathrm{ab}}$ & $285.28^{\mathrm{a}}$ & $0.75^{\mathrm{ab}}$ & $139.83^{\mathrm{ab}}$ & $805.29^{a}$ & $6.69^{\mathrm{a}}$ \\
\hline NPK $100 \%+Z n(F S)$ & $107.68^{\mathrm{a}}$ & $391.30^{\mathrm{a}}$ & $324.87^{\mathrm{a}}$ & $0.60^{\mathrm{ab}}$ & $149.83^{\mathrm{ab}}$ & $776.03^{\mathrm{a}}$ & $6.73^{\mathrm{a}}$ \\
\hline NPK $80 \%+Z n(S A)$ & $106.14^{\mathrm{a}}$ & $357.79^{b}$ & $284.38^{\mathrm{a}}$ & $0.78^{a}$ & $158.33^{\mathrm{a}}$ & $776.40^{\mathrm{a}}$ & $6.94^{\mathrm{a}}$ \\
\hline NPK $80 \%+Z n(R D)$ & $106.37^{\mathrm{a}}$ & $415.11^{\mathrm{a}}$ & $280.78^{\mathrm{a}}$ & $0.58^{\mathrm{b}}$ & $156.42^{\mathrm{a}}$ & $685.31^{\mathrm{a}}$ & $6.38^{\mathrm{a}}$ \\
\hline NPK $80 \%+Z n(F S)$ & $108.58^{a}$ & $379.53^{\mathrm{ab}}$ & $323.07^{\mathrm{a}}$ & $0.64^{\mathrm{ab}}$ & $125.50^{\mathrm{ab}}$ & $778.80^{\mathrm{a}}$ & $6.48^{\mathrm{a}}$ \\
\hline NPK $65 \%+Z n(S A)$ & $106.73^{\mathrm{a}}$ & $415.98^{\mathrm{a}}$ & $260.98^{\mathrm{a}}$ & $0.61^{\mathrm{ab}}$ & $152.50^{\mathrm{ab}}$ & $743.01^{\mathrm{a}}$ & $6.04^{\mathrm{a}}$ \\
\hline NPK $65 \%+Z n(R D)$ & $103.99^{\mathrm{a}}$ & $387.32^{\mathrm{ab}}$ & $268.18^{\mathrm{a}}$ & $0.65^{\mathrm{ab}}$ & $151.33^{\mathrm{ab}}$ & $648.92^{\mathrm{a}}$ & $5.96^{\mathrm{a}}$ \\
\hline NPK 65\%+Zn (FS) & $106.41^{\mathrm{a}}$ & $399.46^{\mathrm{ab}}$ & $278.98^{\mathrm{a}}$ & $0.63^{\mathrm{ab}}$ & $110.33^{b}$ & $690.64^{\mathrm{a}}$ & $6.10^{\mathrm{a}}$ \\
\hline$C V(0.05 \%)$ & 3.510 & 7.547 & 16.398 & 16.482 & 18.548 & 20.881 & 9.243 \\
\hline \multicolumn{8}{|c|}{ Maha season } \\
\hline NPK 100\% & $112.41^{\mathrm{A}}$ & $369.57^{\mathrm{BCD}}$ & $370.47^{\mathrm{AB}}$ & $1.75^{\mathrm{A}}$ & $105.00^{\mathrm{A}}$ & $977.85^{\mathrm{A}}$ & $4.83^{\mathrm{A}}$ \\
\hline NPK 100\%+Zn (SA) & $111.25^{\mathrm{A}}$ & $397.68^{\mathrm{AB}}$ & $387.68^{\mathrm{AB}}$ & $1.65^{\mathrm{AB}}$ & $90.58^{\mathrm{A}}$ & $1015.52^{\mathrm{A}}$ & $4.58^{\mathrm{A}}$ \\
\hline NPK $100 \%+Z n(R D)$ & $112.07^{\mathrm{A}}$ & $335.14^{\mathrm{DE}}$ & $395.83^{\mathrm{AB}}$ & $1.76^{\mathrm{A}}$ & $96.58^{\mathrm{A}}$ & $1081.70^{\mathrm{A}}$ & $3.75^{\mathrm{A}}$ \\
\hline NPK $100 \%+Z n(F S)$ & $113.78^{\mathrm{A}}$ & $386.78^{\mathrm{ABC}}$ & $413.04^{\mathrm{A}}$ & $1.74^{\mathrm{A}}$ & $102.13^{\mathrm{A}}$ & $989.58^{\mathrm{A}}$ & $4.48^{\mathrm{A}}$ \\
\hline $\mathrm{NPK} 80 \%+\mathrm{Zn}(\mathrm{SA})$ & $109.80^{\mathrm{A}}$ & $354.17^{\mathrm{CD}}$ & $376.81^{\mathrm{AB}}$ & $1.82^{\mathrm{A}}$ & $111.42^{\mathrm{A}}$ & $973.45^{\mathrm{A}}$ & $4.90^{\mathrm{A}}$ \\
\hline NPK $80 \%+Z n(R D)$ & $109.04^{\mathrm{A}}$ & $352.66^{\mathrm{CD}}$ & $365.94^{\mathrm{AB}}$ & $1.42^{\mathrm{C}}$ & $106.83^{\mathrm{A}}$ & $1042.29^{\mathrm{A}}$ & $4.29^{\mathrm{A}}$ \\
\hline NPK $80 \%+Z n(F S)$ & $108.32^{\mathrm{A}}$ & $346.92^{\mathrm{DE}}$ & $373.19^{\mathrm{AB}}$ & $1.58^{\mathrm{ABC}}$ & $99.92^{\mathrm{A}}$ & $900.49^{\mathrm{A}}$ & $3.94^{\mathrm{A}}$ \\
\hline $\mathrm{NPK} 65 \%+\mathrm{Zn}(\mathrm{SA})$ & $111.29^{\mathrm{A}}$ & $410.37^{\mathrm{A}}$ & $377.72^{\mathrm{AB}}$ & $1.44^{\mathrm{BC}}$ & $102.75^{\mathrm{A}}$ & $919.24^{\mathrm{A}}$ & $4.85^{\mathrm{A}}$ \\
\hline NPK $65 \%+Z n(R D)$ & $106.58^{\mathrm{A}}$ & $314.71^{\mathrm{E}}$ & $347.83^{\mathrm{B}}$ & $1.49^{\mathrm{BC}}$ & $90.75^{\mathrm{A}}$ & $856.71^{\mathrm{A}}$ & $3.85^{\mathrm{A}}$ \\
\hline NPK 65\%+Zn (FS) & $114.03^{\mathrm{A}}$ & $336.47^{\mathrm{DE}}$ & $367.75^{\mathrm{AB}}$ & $1.47^{\mathrm{BC}}$ & $88.75^{\mathrm{A}}$ & $928.35^{\mathrm{A}}$ & $4.40^{\mathrm{A}}$ \\
\hline$C V(0.05 \%)$ & 4.093 & 6.527 & 7.797 & 8.996 & 14.157 & 23.701 & 17.918 \\
\hline
\end{tabular}

Mean values with the same letter are not statistically significant at the same column in each season at $\mathrm{p} \leq 0.05$.

tistically insignificant yields among the different methods of application of $\mathrm{Zn}$, the root dipping can be identified as the easy and lowcost method for the application of $\mathrm{ZnSO}_{4}$ considering the labour requirement, time spent and the materials used. Similar results were found by Begum et al. in 2003, identifying root dipping as a cost-effective and convenient method for $\mathrm{Zn}$ application out of various rates and methods tested for transplant rice cultivar BR26.

Similar research conducted by Khan et al. (2003) using seedling root dipping in $1 \%$ $\mathrm{ZnSO}_{4}, 0.2 \% \mathrm{ZnSO}_{4}$ foliar spray after trans- planting and $10 \mathrm{~kg} / \mathrm{ha}$ soil application, also reported insignificant differences among three treatments in the number of tillers $/ \mathrm{m}^{2}$, spikelets/panicle, \% filled grains, 1000 seed weight, and straw yield/ha. However, a significantly higher yield was observed in the treatment where $\mathrm{ZnSO}_{4}$ was broadcasted to the soil. Various other researches have reported controversial results than we observed. An experiment done by Mustafa et al. (2011) for Supper Basmathi rice variety reported a significantly higher yield in treatment with the basal application at the rate of $25 \mathrm{~kg} / \mathrm{ha}$. Jatav and Singh (2018) reported considerably higher growth and yield with the incorporation of 
Table 2: Effect of rate of application of NPK and method of application of $\mathrm{ZnSO}_{4}$ on seed quality of rice var. At 362

\begin{tabular}{|c|c|c|c|c|c|c|c|c|}
\hline \multicolumn{9}{|c|}{ Yala season } \\
\hline Treatment & BR\% & TMR\% & HG\% & $\begin{array}{l}\text { Husk } \\
\text { weight } \\
\text { (g/ kg) }\end{array}$ & $\begin{array}{l}\text { Bran } \\
\text { weight } \\
\text { (g/ kg) }\end{array}$ & $\begin{array}{l}1000 \\
\text { grains } \\
\text { weight } \\
(\mathrm{g}) \\
\end{array}$ & $\begin{array}{l}\text { Grain } \\
\text { length } \\
(\mathrm{mm})\end{array}$ & $\begin{array}{l}\text { Grain } \\
\text { width } \\
\text { (mm) }\end{array}$ \\
\hline NPK $100 \%$ & $79.56^{\mathrm{a}}$ & $89.60^{\mathrm{a}}$ & $70.15^{\mathrm{a}}$ & $203.84^{b}$ & $88.08^{\mathrm{a}}$ & $25.35^{\mathrm{abc}}$ & $6.55^{c}$ & $2.19^{\mathrm{d}}$ \\
\hline NPK $100 \%+Z n(S A)$ & $79.76^{\mathrm{a}}$ & $89.43^{\mathrm{a}}$ & $66.37^{\mathrm{a}}$ & $200.25^{b}$ & $84.46^{\mathrm{a}}$ & $25.69^{\mathrm{a}}$ & $6.57^{\mathrm{ab}}$ & $2.23^{\mathrm{bcc}}$ \\
\hline NPK $100 \%+Z n(R D)$ & $80.05^{\mathrm{a}}$ & $89.08^{\mathrm{ab}}$ & $67.68^{\mathrm{a}}$ & $198.33^{b}$ & $84.54^{\mathrm{a}}$ & $25.36^{\mathrm{ab}}$ & $6.55^{\mathrm{bc}}$ & $2.24^{\mathrm{bc}}$ \\
\hline NPK $100 \%+Z n(F S)$ & $80.10^{\mathrm{a}}$ & $89.13^{\mathrm{ab}}$ & $66.83^{\mathrm{ab}}$ & $197.06^{b}$ & $90.92^{\mathrm{a}}$ & $25.64^{\mathrm{abc}}$ & $6.58^{\mathrm{a}}$ & $2.27^{\mathrm{bcd}}$ \\
\hline NPK $80 \%+Z n(\mathrm{SA})$ & $79.91^{\mathrm{a}}$ & $88.96^{b}$ & $67.55^{\mathrm{a}}$ & $198.63^{b}$ & $83.45^{\mathrm{a}}$ & $25.21^{\mathrm{abc}}$ & $6.50^{c}$ & $2.30^{\mathrm{a}}$ \\
\hline $\mathrm{NPK} 80 \%+\mathrm{Zn}(\mathrm{RD})$ & $79.49^{a}$ & $89.01^{\mathrm{ab}}$ & $69.08^{a}$ & $203.15^{b}$ & $86.59^{a}$ & $25.62^{\mathrm{bc}}$ & $6.41^{c}$ & $2.20^{\mathrm{bcd}}$ \\
\hline NPK $80 \%+Z n(F S)$ & $79.68^{a}$ & $89.46^{\mathrm{ab}}$ & $70.01^{\mathrm{a}}$ & $201.19^{b}$ & $90.77^{\mathrm{a}}$ & $25.63^{\mathrm{a}}$ & $6.37^{\mathrm{e}}$ & $2.23^{\mathrm{cd}}$ \\
\hline NPK $65 \%+Z n(S A)$ & $78.88^{\mathrm{a}}$ & $88.97^{\mathrm{ab}}$ & $57.68^{\mathrm{ab}}$ & $208.94^{b}$ & $88.94^{\mathrm{a}}$ & $24.80^{\mathrm{bc}}$ & $6.40^{\mathrm{e}}$ & $2.21^{\mathrm{b}}$ \\
\hline NPK $65 \%+Z n(R D)$ & $78.90^{\mathrm{a}}$ & $89.08^{\mathrm{ab}}$ & $53.07^{\mathrm{ab}}$ & $210.77^{\mathrm{a}}$ & $84.19^{\mathrm{a}}$ & $25.15^{\mathrm{c}}$ & $6.41^{\mathrm{d}}$ & $2.23^{\mathrm{bc}}$ \\
\hline NPK $65 \%+Z n(F S)$ & $80.01^{\mathrm{a}}$ & $89.44^{\mathrm{ab}}$ & $62.09^{b}$ & $197.39^{b}$ & $88.25^{\mathrm{a}}$ & $25.32^{\mathrm{abc}}$ & $6.37^{\mathrm{e}}$ & $2.18^{\text {bcd }}$ \\
\hline$C V(0.05 \%)$ & 0.684 & 0.512 & 9.692 & 2.750 & 5.574 & 1.006 & 0.241 & 1.222 \\
\hline \multicolumn{9}{|c|}{ Maha season } \\
\hline NPK 100\% & $77.96^{\mathrm{A}}$ & $90.91^{\mathrm{A}}$ & $58.12^{\mathrm{A}}$ & $216.09^{\mathrm{A}}$ & $93.17^{\mathrm{A}}$ & $21.41^{\mathrm{A}}$ & $6.35^{\mathrm{D}}$ & $2.15^{\mathrm{B}}$ \\
\hline NPK $100 \%+Z n(S A)$ & $78.16^{\mathrm{A}}$ & $90.97^{\mathrm{A}}$ & $58.60^{\mathrm{A}}$ & $215.22^{\mathrm{A}}$ & $96.53^{\mathrm{A}}$ & $21.50^{\mathrm{A}}$ & $6.68^{\mathrm{A}}$ & $2.24^{\mathrm{A}}$ \\
\hline NPK $100 \%+Z n(R D)$ & $76.48^{\mathrm{A}}$ & $89.56^{\mathrm{A}}$ & $55.94^{\mathrm{AB}}$ & $231.23^{\mathrm{A}}$ & $104.95^{\mathrm{A}}$ & $21.53^{\mathrm{A}}$ & $6.60^{\mathrm{AB}}$ & $2.22^{\mathrm{A}}$ \\
\hline NPK $100 \%+Z n(F S)$ & $77.79^{\mathrm{A}}$ & $90.06^{\mathrm{A}}$ & $47.01^{\mathrm{B}}$ & $219.32^{\mathrm{A}}$ & $110.66^{\mathrm{A}}$ & $21.50^{\mathrm{A}}$ & $6.57^{\mathrm{ABC}}$ & $2.25^{\mathrm{A}}$ \\
\hline NPK $80 \%+Z n(S A)$ & $77.39^{\mathrm{A}}$ & $90.20^{\mathrm{A}}$ & $52.65^{\mathrm{AB}}$ & $223.11^{\mathrm{A}}$ & $101.33^{\mathrm{A}}$ & $21.11^{\mathrm{A}}$ & $6.63^{\mathrm{A}}$ & $2.23^{\mathrm{A}}$ \\
\hline NPK $80 \%+Z n(R D)$ & $77.29^{\mathrm{A}}$ & $90.90^{\mathrm{A}}$ & $60.80^{\mathrm{A}}$ & $220.70^{\mathrm{A}}$ & $98.90^{\mathrm{A}}$ & $21.64^{\mathrm{A}}$ & $6.45^{\mathrm{ABC}}$ & $2.23^{\mathrm{A}}$ \\
\hline NPK $80 \%+Z n(F S)$ & $77.93^{\mathrm{A}}$ & $89.51^{\mathrm{A}}$ & $57.24^{\mathrm{AB}}$ & $218.49^{\mathrm{A}}$ & $99.27^{\mathrm{A}}$ & $21.90^{\mathrm{A}}$ & $6.44^{\mathrm{CD}}$ & $2.23^{\mathrm{A}}$ \\
\hline NPK $65 \%+Z n(S A)$ & $77.62^{\mathrm{A}}$ & $89.71^{\mathrm{A}}$ & $60.63^{\mathrm{A}}$ & $220.52^{\mathrm{A}}$ & $94.47^{\mathrm{A}}$ & $21.83^{\mathrm{A}}$ & $6.59^{\mathrm{ABC}}$ & $2.21^{\mathrm{A}}$ \\
\hline NPK $65 \%+Z n(R D)$ & $77.69^{A}$ & $89.46^{\mathrm{A}}$ & $53.16^{\mathrm{AB}}$ & $221.02^{\mathrm{A}}$ & $98.65^{\mathrm{A}}$ & $21.65^{\mathrm{A}}$ & $6.53^{\mathrm{ABC}}$ & $2.23^{\mathrm{A}}$ \\
\hline NPK $65 \%+Z n(F S)$ & $78.61^{\mathrm{A}}$ & $89.89^{\mathrm{A}}$ & $59.48^{\mathrm{A}}$ & $212.18^{\mathrm{A}}$ & $95.19^{\mathrm{A}}$ & $21.43^{\mathrm{A}}$ & $6.54^{\mathrm{ABC}}$ & $2.24^{\mathrm{A}}$ \\
\hline$C V(0.05 \%)$ & 1.603 & 1.012 & 7.526 & 4.291 & 7.221 & 2.034 & 0.915 & 1.147 \\
\hline
\end{tabular}

Mean values with the same letter are not statistically significant at the same column in each season at $\mathrm{p} \leq 0.05$. BR\%; the percentage of brown rice, $\mathrm{TMR} \%$; total milled rice percentage and, $\mathrm{HG} \%$; head grain percentage.

$5 \mathrm{~kg} \mathrm{ha}^{-1}$ of $\mathrm{ZnSO}_{4}$ to paddy soil, root dipping with $0.5 \%$ solution of $\mathrm{ZnO}$ and foliar application of $0.5 \% \mathrm{ZnSO} 4$ solution with $0.25 \%$ lime. The treatments with all modes of $\mathrm{Zn}$ application in Jatav and Singh's (2018) experiment reported the highest performances in hybrid rice variety Arize-6444. The highest extractable $\mathrm{Zn}$ content at the postharvest soil of the paddy field was also observed by them in the conjoint application of Zn. Similar results were published by Ghoneim (2016) and Khan et al. (2003). Ghoneim (2016) has applied $\mathrm{Zn}$ fertilizer using different methods to an Egyptian rice variety Sakha 104 and found higher growth and yield of rice along with a higher amount of $\mathrm{Zn}$ in the soil after harvesting. According to his findings, the $\mathrm{Zn}$ content in the soil after paddy harvesting is significantly affected by the application method. The soil application of $\mathrm{Zn}$ significantly increases the postharvest $\mathrm{Zn}$ content of the soil. However, the amount of $\mathrm{ZnSO}_{4}$ applied $(15 \mathrm{~kg} / \mathrm{ha})$ in his experiment was considerably greater than that of the present study. These results indicate that the necessity of prior soil testing before the application of $\mathrm{Zn}$ fertilizer. The field in which the present study was conducted, had been used continuously for paddy cultivation. Therefore, one possibility of statistically insignificant results of this study might be the 
amount of $\mathrm{Zn}$ fertilizer applied in previous seasons. These postharvest $\mathrm{Zn}$ amounts might have satisfied the $\mathrm{Zn}$ requirement of rice.

The other possibility is the increase in nutrient use efficiency by $\mathrm{Zn}$ fertilizer. This phenomenon has previously been reported by Rahman et al. (2002). They have done a pot experiment using various types of $\mathrm{N}$ fertilizers and with or without $\mathrm{Zn}$ fertilizers and observed a 9 $-28 \%$ increase of $\mathrm{N}$ use efficiency along with greater grain and straw yields. Therefore, the insignificant results observed in this study for yield variation among treatments might be due to the increase of fertilizer use efficiency. Therefore, further experiments with different amount of N:P:K fertilizers and $\mathrm{Zn}$ fertilizer application methods can be suggested, aiming at possible reduction of NPK fertilizer application.

Although the $\mathrm{Zn}$ content in grains was not measured in the present study, an objective of the application of $\mathrm{Zn}$ fertilizer is to increase $\mathrm{Zn}$ content in grains to reduce human $\mathrm{Zn}$ deficiencies. Therefore, further research not only on the rate and method of application of $\mathrm{Zn}$ but also different sources of $\mathrm{Zn}$ fertilizer is important to enhance the $\mathrm{Zn}$ use and partitioning efficiencies.

\section{CONCLUSION}

The statistically insignificant results observed in both seasons indicated that there is no effect of the rate and method of application of $\mathrm{Zn}$ on growth, yield and some grain quality attributes of rice variety At 362 . However, the results imply that the possibility of reducing NPK fertilizer up to $65 \%$ without significant yield loss, with $\mathrm{Zn}$ as a soil application, root dipping and foliar spray. Considering the different rates and methods of application of $\mathrm{ZnSO}_{4}$ in this study, it can be said that the root dipping treatment with $65 \%$ NPK level requires less labour, time and materials. However, further experiments on $\mathrm{Zn}$ content in the soil after paddy harvesting, amount of $\mathrm{Zn}$ in grains and straw, efficiencies of various $\mathrm{Zn}$ sources, and the effect of other agronomic practices on $\mathrm{Zn}$ retention and nutrient use efficiency should be conducted to understand the complete picture of the behaviour of $\mathrm{Zn}$ in paddy soil.

\section{Author contribution}

KHCHK and RFH conceptualized and designed the study. KHCHK performed the experiments. DLW analyzed and interpret the data. MKPNM and DLW contributed in drafting the manuscript and DLW critically revised the manuscript.

\section{References}

Abdullah AB, Ito S and Adhana K 2006. Estimate of rice consumption in Asian countries and the world towards 2050. Proceedings for Workshop and Conference on Rice in the World at Stake 2: $28-43$.

Alloway BJ 2008 Zinc in soils and crop nutrition. International Zinc Association and International fertilizer industry association, 2nd edition, Brussels, Belgium and Paris, France.

Bandara WMJ, Kumaragamage D, Wikramasinghe $\mathrm{DB}$ and Weerawarna SBA 2006 A site-specific fertilizer recommendation for rice grown in imperfectly drained reddish-brown earth soil in low country dry zone of Sri Lanka. Tropical Agriculturist 18:48-62.

Begum M, Noor M, Miah H and Basher MM 2003 Effect of rate and method of zinc application on growth and yield of Aus Rice. Pakistan Journal of Biological Sciences 6(8):688-692.

Cakmak I 2000a Role of zinc in protecting plant cells from reactive oxygen species. New Phytologist 146:185-205.

Cakmak I 2000b Possible roles of zinc in protecting plant cells from damage by reactive oxygen species. New Phytologist 146:185-205.

Cakmak I 2008 Enrichment of cereal grains with zinc: agronomic or genetic biofortification? Plant Soil 302, 1-17.

Chandrajith R, Dissanayake CB, Tobschall HJ 2005 Geochemistry of trace elements in paddy (rice) soils of Sri LankaImplications for iodine deficiency disorders (IDD). Environ Geochem Health 27(1):55-64. doi: 10.1007/ s10653-004-2290-2 
Chang HB, Win Lin C and Huang HJ 2005 Zinc induced cell death in rice (Oryza sativa L.) roots. Plant Growth Regulation 46:261-266.

Chen W, Yang X, He Z, Feng Y, Hu F 2008 Differential changes in photosynthetic capacity, $77 \mathrm{~K}$ chlorophyll fluorescence and chloroplast ultrastructure between Znefficient and Zn-inefficient rice genotypes (Oryza sativa) under low zinc stress. Physiologia Plantarum 132:89-101.

Chhabra V and Kumar R 2018 Role of zinc application on rice growth and yield. Plant Archives 18(2):13821384.

Fageria NK, Baligar VC and Clark RB 2002 Micronutrients in crop production. AdvAgron 77:185-268.

FAO 2008 Crop prospects and food situation. 5th Report. United Nations, Rome: 89.

Fitzgerald MA, Mccouch SR and Hall RD 2009. Not just a grain of rice: The quest for quality. Trends Plant Science 14(3):133-139.

Ghoneim AM 2016 Effect of different methods of Zn application on rice growth, yield and nutrients dynamics in plant and soil. Journal of Agriculture and Ecology Research International 6(2):1 $-9$.

Jatav SS and Singh SK 2018 Evaluation of different methods of Zinc application on growth and yield of hybrid rice (Oryza sativa L.) in inceptisol of Varanasi. Journal of Pharmacognosy and Phytochemistry 7(4):1739-1744.

Khan MU, Qasim M, Subhan M, Jamil M and Ahmad RD 2003 Response of rice to different methods of zinc application in calcareous soil. Pakistan Journal of Applied Sciences 3(7):524-529.

Mustafa G, Enshanullah, Akbar N, Qaisrani $\mathrm{SA}$, Iqbal A, Khan ZH, Jabran $\mathrm{K}$, Chattha AA, Trethowan R, Chattha T and Atta BM 2011Effect of zinc application on growth and yield of rice. International Journal of Agro Vetanary and Medical Sciences 5 (6): 530-535.

Quijano-Guerta C, Kirk GJD, Portugal AM, Bartolome VI and McLaren GC 2002
Tolerance of rice germplasm to zinc deficiency. Field Crops Res 76:123130.

Rahman MA, Jahiruddin $M$ and Islam MR 2007 Critical limit of zinc for rice in calcareous soils. Journal of Agriculture \& Rural Development 5(1\&2):43-47.

Rahman A, Yasin M, Akram M and Awan ZI 2002 Response of rice to zincapplication and different $\mathrm{N}$-sources in calcareous soil. Science Vision 8 (1):100-104.

Rana WK and Kashif SR 2014 Effect of different Zinc sources and methods of application on rice yield and nutrients concentration in rice grain and straw. Journal of Environmental and Agricultural Sciences: 1-9.

Rehman HU, Aziz T, Farooq M, Wakeel A and Rengel Z 2012 Zinc nutrition in rice production systems: a review. Plant and soil 361(1-2):203-226.

Rehmani MIA, Wei G, Hussain N, Ding C, Li G, Liu Z, Wang S and Ding Y 2014 Yield and quality responses of two indica rice hybrids to post-anthesis asymmetric day and night open-field warming in lower reaches of Yangtze River delta. Field Crops Research 156:231-241.

Tiong J, McDonald GK, Genc Y, Pedas P, Hayes JE, Toubia J, Langridge $P$ and Huang CY 2014 HvZIP7 mediates zinc accumulation in barley (Hordeum vulgare) at moderately high zinc supply. New Phytologist 201(1): 131-143.

USDA, Foreign Agricultural service 2020 Grain and feed annual. https:// www.fas.usda.gov/data/sri-lanka-grain -and-feed-annual. Retrieved on 202101-12. 